\title{
Mexico's 2018 Report Card on Physical Activity for Children and Youth: Full report
}

\author{
Gabriela Argumedo, ${ }^{1}$ Juan Ricardo López y Taylor, ${ }^{2}$ Alejandro Gaytán-González, ${ }^{2}$ \\ Inés González-Casanova, ${ }^{3}$ Martín Francisco González Villalobos, ${ }^{2}$ Alejandra Jáuregui, ${ }^{4}$ Edtna Jáuregui \\ Ulloa, ${ }^{2}$ Catalina Medina, ${ }^{4}$ Yoali Selene Pacheco Miranda, ${ }^{5}$ Marcela Pérez Rodríguez, ${ }^{6}$ Eugen Resendiz, ${ }^{4}$ \\ Ricardo Alejandro Retano Pelayo, ${ }^{2}$ María del Pilar Rodríguez Martínez ${ }^{7}$ and Karla I. Galaviz ${ }^{3}$
}

Suggested citation Argumedo G, Taylor JRL, Gaytán-González A, González-Casanova I, Villalobos MFG, Jáuregui, A, et al. Mexico’s 2018 Report Card on Physical Activity for Children and Youth: Full report. Rev Panam Salud Publica. 2020;44:e26. https://doi.org/10.26633/ RPSP.2020.26

ABSTRACT

Objectives. Mexico's 2018 Report Card evaluates the opportunities available for Mexican children and youth to reach healthy levels of physical activity, sleep, and sedentary behavior.

Methods. The Report Card is a surveillance system that gathers data from national surveys, censuses, government documents, websites, grey literature, and published studies to evaluate 16 indicators in four categories: Daily Behaviors; Physical Fitness; Settings and Sources of Influence; and Strategies and Investments. Data were compared to established benchmarks. Each indicator was assigned a grade from $1-10$ ( $<6$ is a failing grade) or "incomplete" if data was insufficient/unavailable.

Results. Daily Behavior grades were: Overall Physical Activity, 4; Organized Sport Participation, 5; Active Play, 3; Active Transportation, 5; Sleep, 7; and Sedentary Behavior, 3. Physical Fitness, received a 7. Settings and Sources of Influence grades were: Family and Peers, incomplete; School, 3; and Community and Environment, 4. Strategies and Investments were: Government Strategies, 6; and Non-Government Organizations, 2.

Conclusion. Low grades in 11 of the 16 indicators indicate that schools, families, communities, and government need to work together to improve physical activity opportunities for children and youth in Mexico.

Keywords: $\quad$ Physical fitness; child health; youth sports; health behavior; public health surveillance; health promotion; Mexico.

Movement behaviors, namely physical activity, sleep, active play, and sedentary behavior are strong independent factors influencing children's health (1). Evidence-based guidelines recommend children 5 - 17 years of age accumulate 60 minutes of moderate to vigorous physical activity (MVPA) every day (2), spend no more than 2 hours per day in recreational screen time, sleep 8 - 11 hours per night, and spend several hours engaged in a variety of structured and unstructured light

\footnotetext{
Department for Health, University of Bath, Bath, Somerset, United Kingdom.

2 Instituto de Ciencias Aplicadas a la Actividad Física y al Deporte, Departamento de Ciencias del Movimiento Humano, Centro Universitario de Ciencias de la Salud, Universidad de Guadalajara, Guadalajara, Jalisco, México.

3 Hubert Department of Global Health, Rollins School of Public Health, Emory University, Atlanta, Georgia, United States of America. $\triangle$ Karla I. Galaviz, kgalavi@emory.edu

4 Departamento de Actividad Física y Estilos de Vida Saludables, Centro de Investigación en Nutrición y Salud, Instituto Nacional de Salud Pública, Cuernavaca, México.
}

\footnotetext{
Departamento de Alimentación, Cultura y Ambiente, Instituto Nacional de Salud Pública, Cuernavaca, México.

6 Centro de Adiestramiento en Investigación Clínica, División de Desarrollo de la Investigación Instituto Mexicano del Seguro Social, Ciudad de México, México.

Centro de Educación Física y Salud Integral, Instituto Tecnológico y de Estudios Superiores de Occidente, Tlaquepaque, Jalisco, México.
} 
physical activities (1). More than $40 \%$ of Mexican children do not meet these recommendations, and this shortfall may contribute to the rising prevalence of obesity and cardio-metabolic disorders observed in this population (3). Since adequate levels of physical activity, sleep, and sedentary behavior are associated with lower adiposity and better cardio-metabolic health (4), implementing strategies to improve these behaviors in Mexico is imperative.

Mexico's Report Card on Physical Activity for Children and Youth aims to evaluate opportunities available for the country's children and youth to engage in health-enhancing movement behaviors. It is framed on an ecological perspective that considers how sociocultural and physical environmental factors and their interactions affect an individual's behavior (5). The Report Card is part of the Global Matrix 3.0, a global surveillance system across 49 countries, including Mexico (6). An abstract summarizing Mexico's grades for 11 indicators reported in the Global Matrix 3.0 has been published elsewhere (7). The purpose of this paper is to provide a full report of the 16 indicators in Mexico's 2018 Report Card-11 Global Matrix indicators and five additional indicators. This full report identifies potential strategies to improve physical activity opportunities for Mexican children and youth.

\section{MATERIALS AND METHODS}

The Report Card is a surveillance system that uses secondary data to monitor physical activity levels in and opportunities for children. The study was conducted through three main steps: (i) identify data sources for each indicator; (ii) compare the data to established benchmarks; and (iii) assign a grade to every indicator. Grades are assigned by a panel of researchers, government and health care practitioners, and public health experts.

Mexico's 2018 Report Card has 16 indicators grouped into four categories: I. Daily Behaviors (Overall Physical Activity, Organized Sports and Physical Activity Participation, Active Play, Active Transportation, Sedentary Behavior, and Sleep); II. Physical Fitness (Cardiorespiratory Fitness, Body Composition, Flexibility, Muscle Fitness, and Muscle Strength); III. Settings and Sources of Influence (Family and Peers, School, Community, and Environment); and IV. Strategies and Investments (Government and Non-Government Organizations).

The main sources of information consulted were the National Health and Nutrition Survey 2016 (ENSANUT), national census, and reports $(3,8-11)$. Information was also obtained from websites, grey literature, and studies published in 2013 - 2017 that reported data on children and youth from $1-17$ years of age. These were identified in Academic Search Complete, EBSCO host, Web of Science, Medline, SCIELO, Cochrane México, and Biblioteca Virtual en Salud databases (Table 1). Grades were assigned according to the proportion of children and youth meeting the established benchmarks developed for the Global Matrix (6). The criteria for grade assignment are shown in Table 2. Grades < 6 represent failing grades. An "incomplete" grade was assigned when data was insufficient/unavailable for the indicator. For grade assignment, national data took precedence over regional data-to better capture how the country was doing as a whole. Objectively-measured data took precedence over self-reported data, and age and gender disparities were considered.
TABLE 1. Benchmarks and source of information for each indicator assessed in the Mexico 2018 Report Card on Physical Activity for Children and Youth

\begin{tabular}{|c|c|c|}
\hline Indicator & Benchmark(s) & Source \\
\hline $\begin{array}{l}\text { Overall Physical } \\
\text { Activity }\end{array}$ & $\begin{array}{l}\% \text { of children/youth achieving at least } \\
60 \text { minutes of MVPA per day }\end{array}$ & ENSANUT 2016 (3) \\
\hline $\begin{array}{l}\text { Organized Sport } \\
\text { Participation }\end{array}$ & $\begin{array}{l}\% \text { of children/youth in sports or } \\
\text { organized physical activity }\end{array}$ & ENSANUT 2016 (3) \\
\hline Active Play & $\begin{array}{l}\% \text { of children/youth who engage in } \\
\text { unstructured, self-directed active play } \\
\text { for several hours a day }\end{array}$ & Published studies \\
\hline $\begin{array}{l}\text { Active } \\
\text { Transportation }\end{array}$ & $\begin{array}{l}\% \text { of children/youth who use active } \\
\text { transportation to get to/from places }\end{array}$ & $\begin{array}{l}\text { INEGI Survey } 2015 \\
\text { (8) }\end{array}$ \\
\hline Sedentary Behavior & $\begin{array}{l}\% \text { of children/youth that spend less than } \\
2 \text { hours per day on a screen }\end{array}$ & ENSANUT 2016 (3) \\
\hline Sleep & $\begin{array}{l}\% \text { of children } 5-13 \text { years of age } \\
\text { getting } 9-11 \text { hours of uninterrupted } \\
\text { sleep per night } \\
\% \text { of youth } 14-17 \text { years of age getting } \\
8-10 \text { hours of uninterrupted sleep per } \\
\text { night }\end{array}$ & ENSANUT 2016 (3) \\
\hline Body Composition & $\begin{array}{l}\% \text { of children/youth whose values of } \\
z \text {-scores of Body Mass Index for age are } \\
\text { from }-2 \text { SD to }+1 \text { SD }\end{array}$ & ENSANUT 2016 (3) \\
\hline Family and Peers & $\begin{array}{l}\% \text { of parents that facilitate and } \\
\text { encourage physical activity for their } \\
\text { children, } \% \text { of parents that meet } 150 \\
\text { minutes per week of MVPA and are } \\
\text { physically active }\end{array}$ & Published studies \\
\hline School & $\begin{array}{l}\% \text { of students that are offered at least } \\
60 \text { minutes of physical education per } \\
\text { week } \\
\% \text { of schools with physical activity } \\
\text { programs or policies }\end{array}$ & $\begin{array}{l}\text { Report by the } \\
\text { Ministry of } \\
\text { Education (11) and } \\
\text { INEGI (28) }\end{array}$ \\
\hline $\begin{array}{l}\text { Community } \\
\text { and the Built } \\
\text { Environment }\end{array}$ & $\begin{array}{l}\% \text { of communities with infrastructure } \\
\text { that promotes physical activity }\end{array}$ & $\begin{array}{l}\text { National reports of } \\
\text { infrastructure and } \\
\text { urban environment } \\
\text { (9) and } \\
\text { ENVIPE (10) }\end{array}$ \\
\hline $\begin{array}{l}\text { Government } \\
\text { Strategies }\end{array}$ & $\begin{array}{l}\text { Evidence of funds, resources, programs, } \\
\text { leadership, and/or commitment to } \\
\text { promoting physical activity }\end{array}$ & $\begin{array}{l}\text { National reports and } \\
\text { strategies 2014 - } \\
2018(33-35)\end{array}$ \\
\hline $\begin{array}{l}\text { Non-Government } \\
\text { Strategies }\end{array}$ & & $\begin{array}{l}\text { Grey literature, } \\
\text { reports, websites }\end{array}$ \\
\hline
\end{tabular}

\section{RESULTS}

Grades for the 2018 Report Card and for previous years are presented in Table 2.

\section{Daily Behaviors}

Overall Physical Activity: 4. According to ENSANUT 2016 (12), although $60.5 \%$ of youth (15 - 19 years of age) accumulate the recommended 60 minutes of MVPA per day, only $17.2 \%$ of children $10-14$ years of age (an age category included for the first time) do the same. ENSANUT also reveals a higher prevalence of physical activity in 10 - 14-year-old boys $(21.8 \%)$ than girls $(12.7 \%)$, and in 15 - 19-year-old boys $(69.9 \%)$ than girls $(51.2 \%)$. National data for children less than 10 years of 
TABLE 2. Grades ${ }^{\text {a }}$ by physical activity indicator, on Mexico's 2012, 2014, 2016, and 2018 Report Cards on Physical Activity for Children and Youth

\begin{tabular}{|c|c|c|c|c|}
\hline Indicator & 2012 & 2014 & 2016 & 2018 \\
\hline $\begin{array}{l}\text { Overall Physical } \\
\text { Activity }\end{array}$ & 5 & 6 & 6 & 4 \\
\hline $\begin{array}{l}\text { Organized Sports } \\
\text { Participation }\end{array}$ & - & 4 & 4 & 5 \\
\hline Active Play & - & Incomplete & 3 & 3 \\
\hline $\begin{array}{l}\text { Active } \\
\text { Transportation }\end{array}$ & Incomplete & 6 & 5 & 5 \\
\hline Sedentary Behavior & 5 & 4 & 4 & 3 \\
\hline Sleep & - & - & - & 7 \\
\hline Body Composition & - & - & - & 7 \\
\hline Family and Peers & Incomplete & Incomplete & Incomplete & Incomplete \\
\hline School & 3 & 4 & 3 & 3 \\
\hline $\begin{array}{l}\text { Community and the } \\
\text { Built Environment }\end{array}$ & Incomplete & 1 & 4 & 4 \\
\hline $\begin{array}{c}\text { Government } \\
\text { Strategies }\end{array}$ & 7 & 6 & 6 & 6 \\
\hline $\begin{array}{l}\text { Non-Government } \\
\text { Strategies }\end{array}$ & - & - & 2 & 2 \\
\hline $\begin{array}{l}\text { Grading scale: } \\
10(A+)=\text { Succeeding with } \\
9.5(A)=83 \%-93 \% \\
9.0(A-)=80 \%-86 \% \\
8.5(B+)=74 \%-79 \% \% \\
8.0(B)=67 \%-73 \% \\
7.5(B-)=60 \%-66 \% \\
7.0(C+)=54 \%-59 \% \\
6.5(C)=47 \%-53 \% \\
\text { Source: Prepared by the a }\end{array}$ & $\begin{array}{l}94 \%-100 \% \text { of childre } \\
(<6=\text { faling) } \\
6.0(\mathrm{C}-)=40 \%-46 \% \\
5.5(\mathrm{D})=34 \%-39 \% \\
5.0(\mathrm{D})=27 \%-33 \% \\
4.5(\mathrm{D})=2 .-20 \%-26 \% \\
\leq 4(\mathrm{~F})=\leq 20 \% \\
\text { authors from study data }\end{array}$ & & & \\
\hline
\end{tabular}

age were not available. Only regional accelerometry (13) and questionnaire data (14) were found, both showing low levels of physical activity for those less than 10 years of age. Considering this, a grade of 4 was assigned to this indicator.

Organized Sports and Physical Activity Participation: 5. Data from ENSANUT 2016 (12) show 48.6\% of children (10 14 years of age) participated in one or more organized sports during the previous 12 months. The National Index of Youth Participation shows a similar proportion of youth (15 - 19 years of age) engaging in sports, a higher proportion still in rural areas (15). This index also shows that sports participation was $4^{\text {th }}$ among activities to perform in spare time (15). Reports from the National Commission on Physical Culture and Sports (16, 17) show a decrease in sports participation by children and youth from 2016 - 2017. Thus, a grade of 5 was assigned to this indicator.

Active Play: 3. Because national data on active play is lacking, to obtain a grade for this indicator, published studies reporting regional data were reviewed. A study conducted in Tlaltizapan, Morelos, of 236 children from $9-12$ years of age found that average, self-reported time spent on active play was $1.8-2.3$ hours per day (18). A study in Mexico City (19) reported that children from $2-5$ years of age spend 3.9 hours per day in active play. A study in Chihuahua, Mexico (20), found that among Tarahumara indigenous groups $(n=50), 45 \%$ of schoolchildren from $6-14$ years of age spend 4 or more hours in active play per week, and among the Mestizo $(n=61), 27 \%$. A multi-city study of 1509 children from 6 - 11 years of age reported that $76 \%$ engage in outdoor play on at least one day per week (21).
Collectively, these studies indicate that Mexican children spend few hours per day engaging in active play (between $2-4$ hours / day), earning this indicator a grade of 3 .

Active Transportation: 5. Mexico's National Institute of Statistics and Geography reports that $54.8 \%$ of children over 3 years of age walk to school, while $1.5 \%$ ride a bicycle (8). According to ENSANUT 2016 (12), among children 10 - 14 years of age, $69 \%$ have an active commute to/from school. In a study of 213 children 10 - 14 years of age in Mexico City (22), 54.5\% of girls and $69.1 \%$ of boys use inactive transportation to school. Since only one-half of Mexican children are active in their commute to/from school, this indicator received a grade of 5 .

Sedentary Behavior: 3. Data from ENSANUT 2016 (3) show that $22.7 \%$ of children $(10-14$ years $)$ and $21.4 \%$ of youth (15 19 years) spend 2 hours or less per day in front of a screen (3). Among the children, more girls (24.4\%) than boys (21.0\%) met the screen time recommendation, while among the youth, more boys $(25.3 \%)$ than girls $(17.4 \%)$ met it. ENSANUT shows more screen time in urban areas than in rural ones, and in children with obesity than in those with normal weight. Higher screen time was also seen in northern parts of Mexico and among children of higher socioeconomic groups (3). Hence, a grade of 3 was assigned.

Regarding other age groups, a study of 365 mothers in a northern city (23) reported that $75 \%$ of their children (8 months 5 years of age) watch television for $1.9-2.5$ hours per day (23). Other studies found that children $6-12$ years of age $(n=60)$ spend an average of 1.6 hours (24) and 10-year-olds spend 2.7 hours per day watching television (25). Among 881 undergraduate students (17 - 19 years of age), a study found that $46.8 \%$ spend 2 hours or less in front of a screen (26). Only one study used accelerometers (27); it found that girls at a private school in Mexico City spent $73.4 \%$ of their time awake engaged in sedentary activities (27).

Sleep: 7. Data from ENSANUT 2016 (3) show that 91\% of children from $10-14$ years of age slept 9 hours or more per night. More girls (95\%) than boys (87\%) met the sleep recommendation for this age group. Girls slept an average of 10.1 hours, and boys, an average of 9.6 hours/night. Among $15-$ 17 -year-olds, $65 \%$ were sleeping at least 8 hours/night. More girls $(68 \%)$ than boys $(62 \%)$ met the sleep recommendations. In this age group, girls slept 7.5 hours/night on average, and boys, 7.4 hours (3). Based on these national data, this indicator received a grade of 7 .

\section{Physical Fitness}

Four indicators in this group--Cardiorespiratory Fitness, Flexibility, Muscle Fitness, and Muscle Strength—were not assigned a grade (see Discussion).

Body Composition: 7. ENSANUT 2016 (3) data show that $66.8 \%$ of $5-11$-year-olds have a healthy Body Mass Index (BMI) for their age; the proportion was similar for boys (66.3\%) and girls $(67.2 \%)$. Among those $12-19$ years of age, $63.7 \%$ have a healthy BMI for their age, with more boys $(66.5 \%)$ than girls $(60.8 \%)$ falling in the normal category (3). Based on this, a grade of 7 was assigned to this indicator. 


\section{Sources of Influence}

Family and Peers: Incomplete. Data on the influence of family and peers on the physical activity of Mexican children and youth are lacking. Hence, an "incomplete" grade was assigned.

School: 3. A report by the Ministry of Education shows 36.3\% of school-aged children in public schools receive 1 hour of physical education (PE) per week (11). Data from the 2013 Basic Education Census (28) by the National Institute of Geography showed that there were 96000 PE teachers at the country's 207 682 public schools (preschool through high school). Based on the shortfall of PE classes and PE teachers, a grade of 3 was assigned to this indicator.

Community and the Built Environment: 4. Data from the National Institute of Statistics and Geography show (9) that one-third of neighborhoods with more than 5000 residents have paved streets and trees, and $45 \%$ have public lighting. The National Registry of Sports Infrastructure (29) reported that in 2015 there were 45497 sports facilities across 32 Mexican states, but data on usage and accessibility are lacking. The 2017 National Victimization Survey (10) found that nearly $75 \%$ of parents stopped allowing their children to go outside due to neighborhood safety concerns. The Ministry of Agriculture, Land, and Urban Development reported that by 2017, new infrastructure developments and/or renovations had improved 1163 public spaces (30); however, green space in Mexico is insufficient, with just $3.8 \mathrm{~m}^{2}$ per inhabitant (31). Regarding infrastructure for active transportation, bikeability, and walkability, improvements have been made in large cities, i.e., Mexico City, Guadalajara, and León (32). Urban mobility programs, such as Bus Rapid Transit, were also launched in many cities to enhance sustainable mobility, but information on fund allocations for these initiatives is lacking. A grade of 4 was assigned to this indicator.

\section{Strategies and Investments}

Government Strategies: 6. According to a 2017 Government National Report (33), the National Sports Infrastructure program received \$ 5867.5 million Mexican pesos in $2013-2017$. During this period, 382 new physical activity-related facilities were developed, 397 were renovated, and 103 were expanded, plus equipment was delivered for several initiatives across the country (34). However, there is no information on the extent to which these resources reached children and youth.

In 2017, Mexico introduced the National Physical Culture and Sports Week. Several activities were promoted through this campaign (e.g., sports, recreational activities) across the country and in a variety of settings (e.g., schools, workplaces). It reached 3035776 people, but how many of these were children and youth is unknown.

In addition, four national initiatives to promote physical activity were identified. México Incluyente reached 4.3 million people through physical education and physical activity in community settings (33). México con Educación de Calidad was directed at enhancing the quality of education through strategies such as professional teacher training and improvements to sports infrastructure and programs in schools (35). Ponte al 100 offered functional capacity assessments for children and adults, along with individual improvement plans at 2828 centers across the country (36). Finally, Muévete en 30 promoted physical activity as a means to prevent obesity, and reached 4 million children and youth (37). The impact and degree to which these initiatives have been implemented is unknown; therefore, a grade of 6 was assigned to this indicator.

Non-Government Strategies: 2. National data on programs and investments by Non-Government Organizations (NGOs) to promote physical activity are lacking. There have been several small initiatives implemented in various parts of the country. Most of these were funded by the food industry, focused on promoting competitive sports, and were small-scale and of short duration. Data on their reach and impact was limited. For this reason, this indicator was assigned a grade of 2 .

The most prominent initiative was the Ponte al 100 program developed by the Fundación Movimiento es Salud in partnership with the federal government, and funded by The Coca-Cola Company (38). Another national initiative was Play 60 Character Camp, sponsored by PepsiCo Incorporated and focused on promoting physical activity in 50 schools; it reached 23000 students (39). Other initiatives funded by the food industry promoted competitive sports participation, e.g., Torneo Futbolito Bimbo and Paly 60 Character Champ. Small initiatives introduced by private foundations were also found. These promoted physical activity promotion, equity, and sports participation, e.g., Fundación Real Madrid and Fundación Mexicanos Activos.

\section{DISCUSSION}

Mexico's 2018 Report Card provides the most comprehensive evaluation of the opportunities available for children and youth to reach adequate levels of physical activity and sleep, and to reduce sedentary behavior. This evaluation shows that movement behaviors are below recommended levels among Mexican children and youth. It also demonstrates that initiatives undertaken by schools, communities, and the government have not achieved sufficient improvements. Gaps remain in monitoring physical activity and behavior in children less than 10 years of age, and on the efforts made by Mexican families to get their children and youth moving.

Grades for Daily Behavior indicators were low, with some grades improving or worsening against the 2016 Report Card. The grade for Physical Activity dropped from 6 in 2016 (40) to 4 in 2018. This was due to low physical activity levels found in the new age group included in ENSANUT 2016 (12): only 17.2\% of 10 - 14-year-olds met the physical activity recommendations. The grade for the Sports Participation indicator increased from 4 in 2016 to 5 in 2018 because the proportion of children and youth participating in Organized Physical Activity or Sports rose from $41.4 \%$ to $48.6 \%$, according to ENSNAUT (12). Sedentary Behavior grades have been steadily declining in every edition of the Report Card, from 5 in 2012 when $50 \%$ of children had less than 2 hours of daily screen time (41), to 3 in 2018 when close to $80 \%$ exceeded the recommended limit.

Other Daily Behaviors did not change or were included for the first time in this evaluation. Sleep, included for the first time, received an encouraging grade of 7 , setting a precedent for future monitoring of this behavior. As with other Daily Behaviors reported in national surveys, there is no sleep data on children less than 10 years of age. The grades for Active Play and Active Transportation remain the same because the data 
used for the first Report Card has not be updated for subsequent Report Cards. New national data are needed to determine if these indicators are changing.

For the first time, Physical Fitness was added to the Report Card, but national data on cardiorespiratory fitness, muscular strength, and flexibility of Mexican children and youth were not found. We could only assess the Body Composition indicator and found that 1 in 3 Mexican children and youth have high BMI for their age (3). Since unhealthy body weight puts children at risk of developing diabetes, cardiovascular disease, and having a shorter lifespan, effective strategies to promote healthy weight in Mexican children and youth are imperative.

The grades for Settings and Sources of Influence indicate physical activity opportunities remain insufficient or are inadequate. As on the 2016 Report Card (40), the grade for the School indicator was 3, given the insufficient PE lessons and PE teachers in public schools $(11,28)$.

The Community and Built Environment indicator received a grade of 4 in the present Report Card, the same as in 2016 (40). More investment is needed to boost the development and recovery of parks and public spaces, as well as to build infrastructure that promotes walking, bike riding, and public transportation use. As in all editions of the Report Card, data are still needed to evaluate efforts that Mexican families are making to encourage physical activity among their children.

The grades for Strategies and Investments suggest insufficient effort to promote physical activity among Mexican children and youth. For the Government indicator, the grade remains at 6 since it was based on programs and initiatives implemented by the same government administration assessed in the 2016 Report Card (40). The degree to which the physical activity strategies were implemented, the proportion of the population reached, and the impact on children and youth are unknown. The level of coordination among the various, relevant government agencies is also unclear. The grade for NGOs remains at 2 , reflecting the lack of information on the reach and impact of their initiatives. Overall, most of these initiatives were funded by the food industry and focused on promoting competitive sports. They were small-scale and of short duration. NGO initiatives should be objectively evaluated to determine their impact and potential, and results should be shared transparently.

Mexico's 2018 Report Card is part of the Global Matrix 3.0, a global initiative aimed at evaluating and comparing standardized scores of physical activity behaviors and opportunities for children and youth. When compared with the 48 participating countries, Mexico ranked $33^{\text {rd }}$ in Overall Physical Activity, $40^{\text {th }}$ in Sources of Influence, and $24^{\text {th }}$ in Daily Behaviors (6). Countries that ranked in first place in Overall Physical Activity and Sources of Influence had a strong and widespread sports culture, infrastructure and policies for active transport, and evidence of existing support from government, schools, and parents. Countries that ranked in first place in Daily Behaviors were those where active transportation is more common than automobile transportation and where access to screen-based recreation is limited (6).

There are numerous opportunities to improve Mexico's global ranking and overall physical activity grades. We offer the following main recommendations:

1. Provide quality physical education to all children in Mexico: this entails training competent PE teachers, providing adequate facilities and equipment, having an inclusive curriculum for all genders and backgrounds, creation of community alliances, and establishing monitoring and evaluation mechanisms.

2. Establish a surveillance system for all movement behaviors and include children from 1 - 18 years of age.

3. Evaluate the impact of existing national policies and programs aimed at promoting physical activity in children and youth, and determine whether each should be continued, modified, or discontinued.

Limitations. This report has certain limitations. Grades were based on national data and do not capture regional variation. Data on movement behaviors come from self-reports, often prone to overestimation. Screen time was used as a proxy indicator of sedentary time, and results were not stratified by type (i.e., watching television, playing video games, or other forms). There are no national data from children less than 10 years of age for any movement behavior; therefore, behaviors in this population could not be assessed. Definitions and measures of Active Play varied, suggesting there is currently no consensus for operationalizing and measuring this behavior. Additionally, the lack of data on family support continues to be a limitation. Lastly, we may have missed sources of information that were not available and/or accessible at the time of this evaluation.

\section{CONCLUSIONS}

Mexico's 2018 Report Card shows children and youth are far from meeting recommended levels of physical activity, sleep, and sedentary behavior. The Report Card also shows that school, community, and government initiatives have been insufficient or inadequate for improving these behaviors. Given the obesity and cardio-metabolic disease epidemic that Mexico is facing, efforts should be directed at promoting health-enhancing physical activity and sleep levels, and combating sedentary behaviors among children and youth. This Report Card can inform school, community, and government strategies to promote active lifestyles for children and youth, so they may become healthy, productive adults who contribute to the development of Mexico.

Author contributions. KIG and JLT designed the study. All authors collected and analyzed the data, interpreted results, and contributed to writing the manuscript. GA and KIG drafted the manuscript. All authors reviewed and approved the final revised version.

Acknowledgements. The authors wish to thank the Active Healthy Kids Global Alliance (Ottawa, Ontario, Canada) for developing the Report Card methodology.

\section{Conflicts of interest. None declared.}

Funding. This work was funded by the University of Guadalajara (Guadalajara, Mexico). KIG was partially supported by the Georgia Center for Diabetes Translation Research (Atlanta, Georgia, United States, P30DK111024). GA was funded by The National Council on Science and Technology of Mexico 
(CONACyT, 409083). The funders had no role in the study design, data collection or analysis, decision to publish, or preparation of the manuscript.
Disclaimer. Authors hold sole responsibility for the views expressed in the manuscript, which may not necessarily reflect the opinion or policy of the RPSP/PAJPH and/or PAHO.

\section{REFERENCES}

1. Tremblay M, Carson V, Chaput J-P, Connor Gorber S, Thy Dinh, Duggan M, et al. Canadian 24-Hour Movement Guidelines for Children and Youth: An Integration of Physical Activity, Sedentary Behavior, and Sleep.Appl Physiol Nutr Metab. 2016;41(6 Suppl 3):S311-S327. doi:10.1139/apnm-2016-0151

2. World Health Organization. Global recommendations on physical activity for health [Internet]. Geneva: WHO; 2010 [cited 2018 June]. Available from: https://www.who.int/dietphysicalactivity/ publications/9789241599979/en/.

3. Instituto Nacional de Salud Pública. Encuesta Nacional de Salud y Nutrición de Medio Camino 2016 [Internet]. México: INSP; 2016 [cited 2018 May 21]. Available from: https://www.insp.mx/avisos/4576-resultados-ensanut-mc-2016.html.

4. Hamilton MT, Hamilton DG, Zderic TW. Role of low energy expenditure and sitting in obesity, metabolic syndrome, type 2 diabetes, and cardiovascular disease. Diabetes. 2007;56(11):2655. doi:10.2337/db07-0882

5. Sallis JF, Cervero RB, Ascher W, Henderson KA, Kraft MK, Kerr J. An ecological approach to creating active living communities. Annu Rev Public Health. 2006;27:297-322. doi:10.1146/annurev. publhealth.27.021405.102100

6. AubertS, Barnes JD, Abdeta C, Abi Nader P, Adeniyi AF, Aguilar-Farias N, et al. Global Matrix 3.0 Physical Activity Report Card Grades for Children and Youth: Results and Analysis From 49 Countries. J Phys Act Health. 2018;15(S2):S251-S73. doi:10.1123/jpah.2018-0472

7. Galaviz KI, Argumedo G, Gaytan-González A, González-Casanova I, González Villalobos MF, Jáuregui A, et al. Results from Mexico's 2018 Report Card on Physical Activity for Children and Youth. J Phys Act Health. 2018;15(S2):S384-S5. doi:10.1123/jpah.2018-0462

8. Instituto Nacional de Estadística y Geografía. Encuesta intercensal [Internet]. 2015 [cited 2018 May 24]. México. Available from: https://www.inegi.org.mx/programas/intercensal/2015/.

9. Instituto Nacional de Estadística y Geografía [Internet]. Resultados sobre infraestructura y características del entorno urbano. 2010 [cited 2018 March 20]. Available from: http:/ /www3.inegi.org.mx/ sistemas/microdatos/default_urbano.aspx.

10. Instituto Nacional de Estadística y Geografía [Internet]. Encuesta Nacional de Victimización y Percepción de Seguridad Pública. 2017 [cited 2018 Feb 28]. Available from: http:/ / www.beta.inegi.org.mx/ proyectos/enchogares/regulares/envipe/2017/.

11. Secretaría de Educación Pública [Internet]. Informe sectorial 1: Educación Física y Deporte en el Sistema Educativo. 2015 [cited 2018 May 20]. Available from: http://www.dgb.sep.gob.mx/ acciones-y-programas /ESDM/Informes_Sectoriales /1_Edu_ Fisica_Deporte_universitario.pdf.

12. Medina C, Jauregui A, Campos-Nonato I, Barquera S. Prevalence and trends of physical activity in children and adolescents: results of the Ensanut 2012 and Ensanut MC 2016. Salud Publica Mex. 2018;60(3):263-71. doi:10.21149/8819

13. Ayala-Guzmán CI, Ramos-Ibánez N, Ortiz-Hernández L. Accelerometry does not match with self-reported physical activity and sedentary behaviors in Mexican children. Bol Med Hosp Infant Mex. 2017;74(4):272-81. doi:10.1016/j.bmhimx.2017.02.006.

14. Trujillo Becerra LB, Nabor Chávez L, Patricia García O, Aracely Anaya-Loyola M. Obesity in Mexican preschooler is associated to low physical activity and diet imbalance. Faseb Journal. 2013;27.

15. Robles G, Ramírez S, Crivelli M, Barbosa J. Índice Nacional de participación juvenil 2015-2016. México D.F. México ; 2016.

16. Comisión Nacional de Cultura Física y Deporte [Internet]. Juegos Nacionales de Educación Media Superior 2017. 2017 [cited 2018 Feb 28]. Available from: http://conadems2017.conade.gob.mx/ BusquedaParticipante.aspx?IDEvento=62.
17. Comisión Nacional de Cultura Física y Deporte [Internet]. Resultados Olimpiada Nacional y Juvenil 2017 [cited 2018 Feb 28]. 2017. Available from: http://olimpiadanacional2017.conade.gob.mx/ ResultadosOlimpiada.aspx.

18. Palos-Lucio G, Flores M, Rivera-Pasquel M, Salgado-de-Snyder VN, Monterrubio E, Henao S, et al. Association between migration and physical activity of school-age children left behind in rural Mexico. Int J Public Health. 2015;60(1):49-58.

19. Martínez-Andrade GO, Cespedes EM, Rifas-Shiman SL, Romero-Quechol G, González-Unzaga MA, Benítez-Trejo MA, et al. Feasibility and impact of Creciendo Sanos, a clinic-based pilot intervention to prevent obesity among preschool children in Mexico City. BMC Pediatr. 2014;14(1).

20. De la Torre-Diaz MdL, Cervantes-Borunda M, Cabanas MD, Benítez-Hernández ZP, López-Ejeda N, Marrodán MD, et al. Food and physical activity differences in mestizos and Tarahumara schoolchildren from Chihuahua city (Mexico). Nutrición Clínica Y Dietética Hospitalaria. 2014;34(2):80-7.

21. Lee RE, Soltero EG, Jáuregui A, Mama SK, Barquera S, Jáuregui E, et al. Disentangling Associations of Neighborhood Street Scale Elements with Physical Activity in Mexican School Children. Environ Behav. 2016;48(1):150-71.

22. Yarabetzy Pantoja I, Sandoval X, Osvaldo Talavera J, Perez M. Physical Activity and Inactivity and its Association with Overweight and Obesity on Children and Adolescents between 10 to 14 Years Old. Faseb J. 2016;30.

23. Diaz-Ramirez G, Jimenez-Cruz A, Souto-Gallardo MD, Bacardi-Gascon M. Effect of the Exposure to TV Food Advertisements on the Consumption of Foods by Mothers and Children. J Pediatr Gastroenterol Nutr. 2013;56(1):86-8.

24. González Devia LJ, Monroy Romero PA, Almonacid Urrego CC, Orjuela OL, Huérfano MJ, Mendieta Zerón H. Comparative study of risk factors related to cardiovascular disease in children from Bogotá, Colombia and Toluca, Mexico. Revista de la Facultad de Ciencias Médicas (Córdoba, Argentina). 2014;71(2):98-105.

25. López-Barron RG, Jiménez-Cruz A, Bacardi-Gascon M. Modifiable environmental obesity risk factors among elementary school children in a Mexico-us border city. Nutr Hosp. 2015;31(5):2047-53.

26. Hidalgo-Rasmussen CA, Ramírez-López G, Hidalgo-San Martín A. Physical activity, sedentary behavior and quality of life in undergraduate adolescents of Ciudad Guzman, State of Jalisco, Mexico. Cienc Saude Coletiva. 2013;18(7):1943-52.

27. Medina C, Barquera S, Katzmarzyk PT, Janssen I. Physical activity during recess among 13-14 year old Mexican girls. BMC Pediatr. 2015;15:17.

28. INEGI-SEP. Censo de Escuelas, Maestros y Alumnos de Educación Básica y Especial [Internet]. 2013 [cited 2018 Feb 28]. Available from: http:/ / cemabe.inegi.org.mx/Reporte.aspx.

29. Comisión Nacional de Cultura Física y Deporte. Censo Nacional de Infraestructura Deportiva [Internet]. 2015 [cited 2018 Feb 28]. Available from: http://sistemas.conade.gob.mx/portalCenso/index_2. aspx.

30. Secretaría de Desarrollo Agrario Territorial y Urbano. Avanza la SEDATU en rescate de espacios públicos y en regeneración urbana [Internet]. 2017 [cited 2018 Aug 31]. Available from: https://www. gob.mx/sedatu/articulos/avanza-la-sedatu-en-rescate-de-espacios-publicos-y-en-regeneracion-urbana?idiom=es.

31. Ciudades Competitivas y Sustentable. Documento Diagnóstico de Rescate de Espacios Públicos. 2014.

32. Aguirre K, Leal-Vallejo A, Treviño-Theesz X, Lazalde H GJ. Ranking de ciclociudades. México: Instituto de Políticas para el Transporte y el Desarrollo; 2015. 
33. Gobierno de los Estados Unidos Mexicanos. Quinto Informe de Ejecución del Plan Nacional de Desarrollo [Internet]. In: Republica Pdl, editor. México 2017 [cited 2018 Aug 31]. Available from:https:// www.gob.mx/cms/uploads/attachment/file/313371/5_IE_PND_ VERSIO_N_FINAL_190318_RGB.pdf.

34. Gobierno de los Estados Unidos Mexicanos. Sexto Informe de Ejecución del Plan Nacional de Desarrollo [Internet]. In: República Pdl, editor. México 2018 [cited 2019 Aug 31]. Available from:http://sil. gobernacion.gob.mx/Archivos/Documentos/2018/09/asun_3730 635_20180901_1535843813.pdf.

35. Gobierno de los Estados Unidos Mexicanos. Plan Nacional de Desarrollo 2013-2018 [Internet]. In: República Pdl, editor. México 2013 [cited 2018 Aug 31]. Available from: http:/ / pnd.gob.mx/.

36. Gobierno de los Estados Unidos Mexicanos. Segundo Informe de Ejecución del Plan Nacional de Desarrollo [Internet]. In: Republica Pdl, editor. México 2014 [cited 2018 Aug 31]. Available from: www. gob.mx/cms/uploads/attachment/file/30345/2_ie_2014_CONSOLIDADO.pdf.

37. Gobierno de los Estados Unidos Mexicanos. Cuarto Informe de Ejecución del Plan Nacional de Desarrollo [Internet]. In: Republica Pdl, editor. México 2016 [cited 2018 Aug 31]. Available from: www.gob.mx/cms/uploads/attachment/file/207257/4_IE_ 2016_21_03_17-ilovepdf-compressed.pdf.
38. Fundación Movimiento es salud. Ponte al 100 [Internet]. [cited 2018 June 31]. Available from: http://www.ponteal100.com.

39. Expok. Fundación PepsiCo México y NFL México benefician a más de 23,000 estudiantes [Internet]. 2017 [cited 2018 June 31]. Available from: https://www.expoknews.com/fundacion-pepsico-mexico-ynfl-mexico-benefician-a-mas-de-23000-estudiantes/.

40. Galaviz KI, Arroyo MA, González-Casanova I, Villalobos MF, Jáuregui A, Ulloa EJ, et al. Results From Mexico's 2016 Report Card on Physical Activity for Children and Youth. J Phys Act Health. 2016;13(11 Suppl 2):S206-S12.

41. Rodríguez MdP, Colley R, Tremblay M, López J, Janssen I, Jáuregui E, et al. Mexico's 2012 Report Card on Physical Activity for Children and Youth. Mexico: CHEO Research Institute, Universidad de Guadalajara, Queen's University; 2012.

Manuscript received on 14 August 2019. Revised version accepted for publication on 15 December 2019.

\section{Boletín sobre actividad física en la población infantil y joven en México, 2018: informe completo}

RESUMEN Objetivos. El boletín de notas de México correspondiente al 2018 evalúa las oportunidades a disposición de la población infantil y joven mexicana para que puedan desarrollar niveles adecuados de actividad física y sueño, y disminuyan el sedentarismo.

Métodos. El boletín es un sistema de vigilancia que recopila los datos obtenidos en las encuestas nacionales, censos, documentos gubernamentales, sitios web, literatura gris y estudios publicados con respecto al análisis de 16 indicadores en 4 categorías: comportamientos diarios, estado físico, entornos y fuentes influyentes, y estrategias e inversión. Los datos fueron cotejados con los puntos de referencia establecidos. A cada indicador se le asignó una calificación entre 1 y 10 (< 6 significa reprobado) o fue marcado como "incompleto" si los datos eran nulos o insuficientes.

Resultados. Las calificaciones obtenidas para los comportamientos diarios fueron: actividad física en general: 4; participación en actividades deportivas organizadas: 5; juego activo: 3; modalidades de transporte activas: 5; sueño: 7; y sedentarismo: 3 . El estado físico obtuvo un 7. Las calificaciones para los entornos y fuentes influyentes fueron: familiares y pares: "incompleto"; escuela: 3; comunidad y entorno: 4. Para las estrategias e inversión: estrategias gubernamentales: 6; entidades no gubernamentales: 2.

Conclusiones. Las bajas calificaciones obtenidas en 11 de los 16 indicadores demuestran que las escuelas, las familias, las comunidades y el gobierno tienen que aunar esfuerzos para mejorar las oportunidades que tiene la población infantil y joven en México para desarrollar niveles de actividad física satisfactorios.

Palabras clave Aptitud física; salud del niño; deportes juveniles; conductas relacionadas con la salud; vigilancia en salud pública; promoción de la salud; México. 


\section{Atividade física entre crianças e jovens no México em 2018: relatório completo}

RESUMO Objetivos. O Report Card de 2018 para o México avalia as oportunidades disponíveis para que crianças e jovens mexicanos atinjam níveis adequados de atividade física, sono e comportamento sedentário.

Métodos. O Report Card é um sistema de vigilância que reúne dados de pesquisas nacionais, censos, documentos governamentais, websites, literatura cinzenta e estudos publicados para avaliar 16 indicadores em quatro categorias: Comportamentos Diários, Forma Física, Ambientes e Influências, e Estratégias e Investimentos. Os dados foram comparados com indicadores de referência estabelecidos. A cada indicador foi atribuída uma pontuação de 1 a 10 (pontuações abaixo de 6 indicam reprovação) ou "incompleta" se os dados fossem insuficientes/indisponíveis.

Resultados. As pontuações para o Comportamento Diário foram as seguintes: atividade física geral: 4; participação em esportes organizados: 5; brincadeiras ativas: 3; transporte ativo: 5; sono: 7; comportamento sedentário: 3. A pontuação para a Forma Física foi de 7. As pontuações para Ambientes e Influências foram: família e amigos, incompleta; escola: 3; comunidade e ambiente: 4. As pontuações para Estratégias e Investimentos foram: estratégias governamentais: 6; organizações não-governamentais: 2.

Conclusão. As pontuações baixas em 11 dos 16 indicadores indicam que as escolas, famílias, comunidades e o governo precisam trabalhar juntos para oferecer mais oportunidades de atividade física às crianças e jovens no México.

Palavras-chave Aptidão física; saúde da criança; esportes juvenis; comportamentos relacionados com a saúde; vigilância em saúde pública; promoção da saúde; México. 